\title{
A IDEOLOGIA DO SIGMA HOJE. NEO- INTEGRALISMO, INTOLERÂNCIA E MEMÓRIA
}

\author{
The Sigma Ideology today - neointegralism, \\ intolerance and memory
}

\author{
Natalia Reis*
}

\begin{abstract}
RESUMO
$\mathrm{O}$ artigo aborda o neo-integralismo, baseado no reavivamento de antigas concepções de mundo e de organização da sociedade do movimento integralista dos anos 30 no Brasil. Entre os elementos presentes no ideário neo-integralista estão a hierarquia, a desigualdade, o racismo e os valores morais e cristãos, que norteiam uma proposta de reconstrução nacional de caráter autoritário e conservador.
\end{abstract}

Palavras-chave: Racismo; Autoritarismo; Conservadorismo.

\begin{abstract}
This article approaches the neo-integralism, based on return of old world and social organization conceptions of the integralist movement in Brazil during thirty'years. The elements presents in neo-integralist ideology are hierarchy, inequality, racism and moral and christian values, that guide an proposition of national construction based on autoritarism and conservadorism.
\end{abstract}

Keywords: Racism; Autoritarism; Conservadorism.

* Doutora em História pela Universidade Federal Fluminense. Professora Titular de História da Universidade Salgado de Oliveira (Rio de Janeiro) 


\section{Considerações Iniciais}

O movimento neo-integralista abarca os atuais seguidores da doutrina integralista preconizada por Plínio Salgado e demais líderes na década de 30, no Brasil. De uma forma geral, os membros deste movimento tentam reativar as idéias, concepções de mundo e de organização da sociedade do antigo movimento integralista, enfatizando a hierarquia, a desigualdade e os preconceitos raciais e sociais, amparados nos valores morais e cristãos.

O movimento vem atuando em diversas frentes. Uma delas é a utilização da Internet como um dos veículos de comunicação dos ideais neo-integralistas. O conteúdo dos sites é constituído de textos de integralistas ilustres - como Plínio Salgado, Miguel Reale e Gustavo Barroso - e de novos integralistas, abordando assuntos atuais do Brasil e do mundo, apresentando as propostas e a doutrina neo-integralista. Os pontos que aparecem nos textos são: críticas ao neoliberalismo e à globalização; críticas ao capitalismo liberal e à internacionalização da economia brasileira; rejeição dos movimentos de cunho esquerdista - como, por exemplo, o MST -, resvalando para o anticomunismo; e defesa do nacionalismo, da pátria, da família e da moral cristã.

Embora os neo-integralistas não possuam uma organização centralizada e não se constituam em um movimento de massa, o uso de um dos mais poderosos meios de comunicação do mundo moderno, a Internet, pode propiciar à doutrina do sigma um alcance imprevisível junto à opinião pública. Vários de seus integrantes fizeram parte do integralismo nos anos 30, outros são descendentes de velhos integralistas e muitos são jovens adeptos, que vêem a doutrina e as propostas políticas integralistas como uma solução para a falta de perspectiva causada pelo modelo de desenvolvimento excludente em vigor no Brasil, resultante das práticas neoliberais e da globalização.

Grande parte de seus membros pertence à camada média baixa e, como mostra a história, as classes médias costumam ser a principal base de apoio para movimentos conservadores, em defesa da manutenção de sua posição na sociedade. Porém, existem também adeptos e filiados das classes operárias, o que nos leva a pensar que, para além dos simples interesses pequeno-burgueses, a ideologia e a visão de mundo propaladas pelo movi- 
mento neo-integralista coadunam-se com um certo "mal-estar" social que atinge a outras camadas da sociedade.

Este mal-estar não pode ser visto unicamente como resultado de motivações econômicas. Antes de tudo, sugere que a sociedade neointegralista a ser construída oferece uma perspectiva de construção de identidades sociais, um projeto de engenharia social, calcado na definição de papéis e lugares, e a consolidação de valores referenciais para a conduta e a relação com o outro. Dessa forma, a doutrina consegue atingir os indivíduos que já não se reconhecem na estrutura social neoliberal, cujas identidades estão destruídas, e que carregam consigo a sensação de inutilidade, causada por uma sociedade na qual o ser humano torna-se descartável e o bem-estar da economia eleva-se a categoria principal.

\section{O Neo-Integralismo e a crise atual}

Nos textos neo-integralistas são recorrentes as análises sobre a situação atual do Brasil, tendo como pano de fundo as propostas do movimento para solucionar os principais problemas do país. É visível a reedição das antigas propostas e posturas defendidas na década de 30 , como a democracia orgânica, o anti-imperialismo, o anti-comunismo e o nacionalismo exacerbado, bem como a crítica ao sistema político liberal.

Os neo-integralistas assumem um posicionamento pequeno-burguês, ao criticarem tanto o capitalismo como o comunismo, pois admitem a manutenção da propriedade, que estaria sendo ameaçada pelo próprio capitalismo, criticam o individualismo capitalista, mas também rejeitam o que chamam de coletivismo propiciado pelo comunismo.

Percebe-se na fala dos neo-integralistas uma característica presente em quase todos os movimentos fascistas: a apropriação de termos ou idéias do socialismo, dando-lhes um novo significado, mais apropriado à proposta conservadora e autoritária de nação. Segundo Konder:

[...] o fascismo foi - pragmaticamente - buscar idéias no campo do inimigo. Numa direita apavorada com a revolução proletária, era natural o impulso de macaqueá-la, "assimilando-a" 
desfigurada para tentar neutralizá-la. Os conservadores puseram-se a ler Marx, a estudar o socialismo. [...] A essência do pensamento de Marx era naturalmente incompatível com os interesses vitais das classes conservado-ras, mas a direita não estava iludida a esse respeito e não tinha a menor intenção de se converter ao marxismo: o que ela queria era "importar" do marxismo alguns conceitos, desligando-os do contexto em que tinham sido elaborados, mistificando-os e tornando-os úteis aos seus propósitos. ${ }^{1}$

No caso dos neo-integralistas, essa estratégia pode ser percebida na forma como eles constroem a crítica ao capitalismo. Parafraseando a análise de Marx, segundo a qual o capitalismo destrói a propriedade privada, pois a retira das mãos da maioria da população e a concentra nas mãos de poucos, os neo-integralistas partem dessa idéia, mas não para abolir de vez a propriedade privada, mas sim para preservá-la. As camadas médias, engolidas pelo capitalismo desenfreado, teriam a sua posição social preservada, isto é, suas propriedades, desde que o próprio capitalismo fosse controlado pelo o que eles chamam de "regulação da produção e do comércio":

A questão social deve ser resolvida pela cooperação de todos, conforme a justiça e o desejo que cada um nutre de progredir e melhorar. O direito de propriedade é fundamental para nós, considerado no seu caráter natural e pessoal. O capitalismo atenta hoje contra esse direito, baseado, como se acha, no individualismo desenfreado, assinalador da fisionomia do sistema econômico liberal-democrático. Temos de adotar novos processos reguladores da produção e do comércio, de modo que o governo possa evitar os desequilíbrios nocivos à estabilidade social. $^{2}$

O comunismo é apresentado de forma totalmente distorcida, chegando-se a equipará-lo ao capitalismo. Ambos são vistos como produzindo o mesmo resultado: o controle da produção nas mãos de uma minoria:

1 KONDER, L. Introdução ao fascismo. Rio de Janeiro: Graal, 1991. p. 8.

2 MANIFESTO INTEGRALISTA 2001. Foz do Iguaçu: Núcleo Integralista de Foz do Iguaçu. Disponível em: <http://www.anauefoz.hpg.ig.com.br/>. Acesso em: 05/04/2008. 
O comunismo não é uma solução, porque se baseia nos mesmos princípios fundamentais do capitalismo, com a agravante de reduzir todos os patrões a um só e escravizar o operariado a uma minoria de funcionários cruéis, recrutados na burguesia. ${ }^{3}$

Apresenta-se nesse trecho uma outra característica própria dos fascismos: os conceitos de capitalismo e comunismo são desligados do objeto ao qual se referem e misturados como se designassem coisas semelhantes. Desconsidera-se, portanto, que os dois conceitos referem-se a sistemas econômicos e políticos completamente distintos e opostos.

Assim, a proposta neo-integralista encaixar-se-ia numa "terceira via", nem comunismo e nem capitalismo, nem individualismo e nem coletivismo, num rearranjo social que permita a ascensão social:

O comunismo destrói a personalidade humana para melhor escravizar o homem à coletividade; destrói a Religião para melhor escravizar o homem aos instintos; destrói a iniciativa de cada um, mata o estímulo, sacrifica uma humanidade inteira, por um sonho falsamente científico, que promete realizar o mais breve possível, isto é, dentro de duzentos anos no mínimo. O que nós desejamos dar ao operário, ao camponês, ao soldado, ao marinheiro é a possibilidade de subir, conforme a sua vocação e seus justos desejos. Pretendemos dar meios a todos para que possam galgar, pelas suas qualidades, pelo trabalho e pela constância, uma posição cada vez melhor; tanto na sua classe como fora dela e até no governo da Nação. [...] Nós ensinamos a doutrina da coragem, da esperança, do amor à Pátria, à Sociedade, à Vida, no que esta tem de belo e de conquistável, da ambição justa de progredir, de possuir bens, de elevar-se e de elevar a família. ${ }^{4}$

A análise da crise atual do país é feita por meio da apropriação das visões da esquerda, redundando em críticas à globalização, ao neoliberalismo e ao imperialismo, apresentando o capitalismo internacional como o responsável pela recessão e o empobrecimento do povo brasileiro.

3 MANIFESTO INTEGRALISTA 2001. Foz do Iguaçu: Núcleo Integralista de Foz do Iguaçu. Disponível em: <http://www.anauefoz.hpg.ig.com.br/>. Acesso em: 05/04/2008.

4 Id. 
Desde que fomos instados a aceitar os figurinos de Bretton Woods (conferência feita em 1944 que criou uma política monetária e comercial entre os Países), vemos nosso País deixar-se dominar por um monetarismo explorador das classes obreiras que as subjuga ao banqueirismo internacional, porquanto este sempre procurou entravar o nosso desenvolvimento, com as inevitáveis imposições recessivas, sugando nossas energias e nosso sangue, através de juros extorsivos e lesivos à sociedade brasileira. Temos vivido em função da dívida externa que, a bem dizer, já foi satisfatóriamente paga. Nestas últimas décadas, nossa submissão ao imperialismo foi mais que nefasta à soberania nacional, de vez que, para enfrentar dívidas contraídas para custear o setor de energia e obras de altos custos (Usinas Nucleares, Transamazônica e outras), fomos forçados a recorrer ao famigerado F.M.I.(Banco Mundial que empresta dinheiro a países que se dispõem a adotar políticas econômicas neoliberais) que impôs nas chamadas "Cartas de Intenções" as mais nefastas condições para que os banqueiros nos atendessem e nos cobrissem de juros altíssimos. Esses atos, os brasileiros já conhecem de sobra, pois redundaram no aumento da recessão, no corte de subsídios a produtos básicos, no achatamento salarial, no desemprego, na fome e na miséria. ${ }^{5}$

A apropriação de uma visão esquerdista na análise da situação do país redunda, no entanto, em uma proposta extremamente conservadora, utilizando-se o conceito marxista de "luta de classes", mas descontextualizando-o. Enquanto para Marx, a luta de classes é algo que pode ser superado através da socialização dos meios de produção, para os neo-integralistas, ela é algo negativo e que deve ser, não superada, mas disciplinada, resultando em uma postura completamente crítica às lutas travadas pelos movimentos sociais que contestam a estrutura social dominante. A idéia de luta de classes é contraposta, portanto, ao ideal nacionalista:

Consequentemente, a miséria e o desemprego desencadearam no País uma onda de episódios violentos sem igual em nossa

5 MANIFESTO INTEGRALISTA2001. Foz do Iguaçu: Núcleo Integralista de Foz do Iguaçu. Disponível em: <http://www.anauefoz.hpg.ig.com.br/>. Acesso em: 05/04/2008. 
história, principalmente nas grandes cidades brasileiras, como assaltos na via pública, nos edifícios, nos automóveis, nos coletivos, nas casas, nos bancos e no comércio. O recrudescimento de greves para a obtenção de melhores salários acirrou a luta de classes em todos os níveis, atingindo as empresas industriais do Estado, Universidades e repartições públicas. Por sua vez, a desagregação moral e social suscitadas pelo desprezo aos valores mais nobres do espírito, que são os valores éticos, tornaram-se cada vez mais avassaladoras com a materialização dos costumes. No rádio, na televisão, no cinema, no teatro, o brasileiro é afrontado com a falta de respeito e abuso de poder. Nesse ambiente desolador, cria-se uma nova geração. Desestabilizada a sociedade, $\boldsymbol{o}$ ideal nacionalista perde o seu ímpeto e sua força. Como conseqüência de tudo isso, vemos, desolados os comunistas se apossarem do poder. Assim, aconteceu na Rússia Soviética, durante a segunda década do Século XX. O poder foi tomado após uma preparação psicológica. É justamente no sentido da elevação do espírito nacional que levantamos a nossa bandeira integralista; uma bandeira que represente, de Fato e de Direito, também a justiça social". ${ }^{6}$

É nesse contexto que entra o que os neo-integralistas designam de "democracia orgânica". Ela permitiria a ordenação dos diversos interesses, preservando-se a harmonia social. Porém, não se fala em interesses de classes, mas de grupos profissionais, defendendo-se o regime corporativo, que seria uma forma de minar a solidariedade de classe, dividindo-a em interesses setoriais. A idéia de democracia orgânica e corporativismo já apareciam no ideal integralista, na década de 30. Mas, no discurso dos neo-integralistas, percebe-se a tentativa de readaptar esta proposta ao contexto atual de fortalecimento dos ideais democráticos. Assim, a idéia de partido único é deixada em segundo plano e procura-se conciliar o corporativismo orgânico com ideais liberais, como liberdade de pensamento e as liberdades democráticas.

Desde 1946, prosseguiu o mesmo ritmo de governos sem programas objetivos, baseado em programas unipessoais. É 
verdade inegável que o país carece de ordenação institucional, com base numa efetiva funcionalidade que dê estabilidade política e social à Nação. E isso, só poderemos conseguir com a implantação de uma DEMOCRACIA ORGÂNICA que, democraticamente, se constitua com a constituição de Câmaras Orgânicas, as quais formariam como auxiliares das câmaras políticas em todos os âmbitos, pois só um regime dessa natureza pode realmente garantir a realidade política e social objetiva, sem a proliferação de crises que tanto tumultuam a vida brasileira. A questão da representatividade poderá ser viabilizada pelas classes profissionais organizadas e que lutem pelos interesses inerentes a cada uma delas, elaborando projetos em suas respectivas câmaras que seriam remetidos às câmaras políticas competentes. O Integralismo, que agora se reorganiza em todo o País, lutará pela implantação da Democracia Orgânica, como Regime Corporativo que será regime aberto ao debate, ao diálogo, não permitindo qualquer tipo de repressão à livre manifestação do pensamento. O regime não aceitará a tutela de partido único e qualquer espécie de ditadura a não ser na sua essência, própria de organização, de onde tira a sua legitimidade de poder. O Integralismo, dentro da Democracia Orgânica, lutará pelo fortalecimento das Forças Armadas, e em qualquer circunstância, pois será autêntico defensor das liberdades democráticas, rigorosamente investidas de responsabilidade, dando-lhes todo o aparelhamento técnico indispensável para o desempenho de sua missão. ${ }^{7}$

A necessidade de readaptar as propostas do movimento ao contexto atual fica clara no seguinte discurso:

Obviamente, que em pleno século XXI, devemos fazer certas ressalvas e reconhecer, como inclusive escreveu o emérito nonagenário Dr. Miguel Reale ainda há poucos meses atrás, a existência de diversos aspectos transitórios e temporários que foram esboçados em linhas gerais de 1932 a 1937. E, portanto, não mais aplicáveis no contexto sócio-econômico em que o Brasil e a maioria das nações importantes hoje se encontram. Não haveria sentido algum, por exemplo, em tentar reeditar as 
propostas da década da trinta do século passado, no sentido da organização jurídica, político e econômica da sociedade e do Estado, tal qual feitas àquela época. Da mesma maneira, após sete décadas, o fabuloso incremento da complexidade dos meios de produção, a evolução tecnológica e o crescimento populacional mundial, levaram a humanidade a uma situação visivelmente diferenciada, em inumeráveis aspectos, sendo que a busca de soluções para os problemas contemporâneos, requer outros enfoques e análises, assim como abordagens focalizadas em uma infinidade de novos aspectos. Esse é um grande desafio que nos depara de imediato. ${ }^{8}$

A despeito dessa constatação, a análise da situação política, econômica e social atual é feita com base numa perspectiva de continuidade dos velhos problemas. A perspectiva continuísta serve para tornar legítimos e defensáveis os mesmos princípios integralistas defendidos na década de 30, conforme o discurso abaixo:

De qualquer forma, [...] ainda podemos reconhecer que os impedimentos para uma verdadeira emancipação da nação permanecem residindo num conjunto de influências nocivas e em obstáculos que o Integralismo, já naquele tempo, se propunha a combater começando por uma revolução interior em cada brasileiro. [...] a realidade continua respondendo a algumas afirmativas que permanecem igualmente inalteradas em nosso cenário político com uma terrível continuidade histórica. Mais do que isso, influenciados por uma ética utilitarista que tem potencializado seus efeitos negativos na civilização ocidental através das décadas, viemos nós brasileiros, durante todo esse período, apenas assistindo sem nenhuma reação condigna os mesmos velhos impedimentos contra a nação metamorfoseando-se constantemente em roupagens diferenciadas, mais complexas e aprofundadas. [...] Continuamos sendo vítimas passivas do imperialismo financeiro das nações hegemônicas forjado por uma determinada e muito bem conhecida oligarquia financeira; Vemos ainda, cerca de

8 SILVEIRA, Marcelo. Integralismo histórico e o integralismo do século XXI. Apresentado no $1^{\circ}$ Congresso do Movimento Integralista Brasileiro para o Século XXI, 2004. Disponível em: <http:// www.integralismo.org.br/novo/ ?cont $=42 \&$ vis $=$ Idem $>$. 
quatro décadas após a contra-revolução de 1964, o socialismo internacional e materialista, agora fortemente inspirado por Gramsci, agindo de forma sub-reptícia na esfera cultural e nas universidades; [...]

Notamos com clareza, a continuidade dos mesmos surrados esquemas políticos e a atuação de partidos que não passam de meras legendas de aluguel sem qualquer sentido social ou institucional [...].Não obstante, uma análise atenta dos resultados civilizatórios visíveis espelhados em nossa própria realidade, $[\ldots]$ nos faz constatar que permanecem mais atuais do que nunca os antigos ideais Integralistas, assim como cada vez mais sufocantes e evidentes, os males e ameaças para que ele advertiu. ${ }^{9}$

A idéia de continuidade na história brasileira permite, portanto, que os neo-integralistas reeditem velhas idéias, baseadas no conservadorismo social, no autoritarismo e na intolerância. A volta dos princípios integralistas é acompanhada, no entanto, de uma tentativa de reconstrução da memória do integralismo, com vistas a legitimá-lo perante a sociedade.

\section{O Neo-Integralismo e o Racismo: anti-semitismo, xenofobia e heterofobia}

A crítica das ideologias que pregam a intolerância às diferenças ou que fundamentam sua doutrina em uma concepção racista é absolutamente necessária enquanto forma de desconstrução do discurso e da prática excludentes e como um meio legítimo de contribuição para o fortalecimento de uma sociedade democrática e igualitária. Contudo, a simples crítica de tais ideologias não coloca automaticamente o crítico do lado da democracia e da igualdade, pelo contrário, muitas vezes o exercício crítico fundamente um outro tipo de intolerância.

9 Id. 
Parto do pressuposto de que a simples crítica das ideologias excludentes não é por si só capaz de definir o posicionamento do portador da crítica no espaço político e social. É preciso analisar de que forma a crítica é construída e quais os ideais políticos que ela reforça. Esta observação encaixa-se na análise do discurso neo-integralista sobre o sionismo.

Visto que não existe neutralidade total, o critério para a diferenciação de uma análise essencialmente ideológica de uma análise científica é a utilização de um aparato instrumental e metodológico capaz de controlar a interferência das ideologias nos resultados do trabalho. Tal aparato reside principalmente no cuidado no trato com as fontes e na operacionalização dos conceitos usados na análise.

O significado de uma fonte não está dado de antemão, é preciso que o pesquisador a interprete e construa seu significado, sendo, portanto, um trabalho de criação. Isso não quer dizer que devamos aceitar qualquer interpretação dada a um discurso, por exemplo. Se o trabalho de interpretação é inevitável, existe, no entanto, as interpretações legítimas e as não legítimas, com base nos critérios de objetividade científica. Quando a ideologia supera a objetividade no processo de análise das fontes, estas adquirem o significado que queremos dar a elas. Um exemplo de análise ideológica das fontes é a realizada pelos neo-integralistas a respeito do texto "A Questão Judaica”, de Karl Marx, no qual haveria supostamente uma postura anti-semita da parte de Marx. Segundo os neo-integralistas:

A tese antijudaica foi o ensaio geral do próprio marxismo [...] Karl Marx elaborou uma nova espécie de teoria da conspiração anti-judaica, que viria a ser o ensaio de sua teoria geral do capital [...] Na segunda parte desse ensaio (A Questão Judaica), Marx questiona e destila o ódio: "Qual é a necessidade profana do judaísmo? A necessidade prática, o interesse próprio. Qual é o culto mundial do judeu? A venalidade (o sangue). Qual o seu Deus universal? O dinheiro [...] O dinheiro degrada todos os deuses da humanidade e os transforma em mercadoria [...] O dinheiro é a essência alienatória do trabalho e da existência do homem. Essa essência o domina e ele a idolatra. O Deus dos judeus secularizou-se e tornou-se o Deus deste mundo. A letra do crédito é o verdadeiro Deus dos judeus." Marx continuou afirmando que os judeus corromperam o mundo inteiro "pela aquisição do poder do dinheiro" e os acusa de transformar o 
dinheiro no "poder mundial; libertando-se da venalidade e do dinheiro, portanto, do judaísmo real e prático, a nossa geração se emanciparia a si própria". ${ }^{10}$

O trecho supracitado apresenta uma simplificação grotesca da obra de Marx, por desconsiderar os pressupostos históricos e sociológicos da questão dos judeus na sociedade capitalista. Os neo-integralistas pretendem mostrar ao público um suposto anti-semitismo de Marx, citando algumas frases contidas na obra em questão, mas desconectadas do seu conjunto e do contexto em que tal obra foi elaborada. Dessa forma, o significado das críticas de Marx às "práticas judaicas" apresenta-se como uma associação direta dos judeus com o capitalismo, desvirtuando-se o seu real significado na obra como um todo.

Quando Marx refere-se às “práticas judaicas”, identificadas com o egoísmo e a usura, ele não estava afirmando que os judeus são os construtores da sociedade capitalista burguesa, mas que a própria sociedade burguesa engendra nos judeus a usura e o egoísmo, visto que determinadas práticas de certos grupos judaicos são práticas da sociedade burguesa. Porém, os neo-integralistas tentam fazer o público acreditar que Marx falava do judaísmo como se este fizesse parte da natureza ou da raça semita, quando, na verdade, ele referia-se ao judeu histórico, cultural e social, engendrado pelas condições históricas e pela sociedade. As "práticas judaicas" da usura e do egoísmo não são, portanto, parte da natureza do judeu enquanto homem ou indivíduo racialmente determinado, mas da cultura judaica, a partir do momento em que os judeus foram historicamente levados à prática do comércio.

Assim, os neo-integralistas desprezam a história dos judeus e o caráter social e cultural do judaísmo, preferindo simplificar a questão das "práticas judaicas", utilizando-se de uma das obras mais importantes de Marx para difundir o anti-semitismo. Nesse caso, é importante ressaltar que a citação da obra A Questão Judaica pelo movimento tem dois objetivos: ocultar o próprio anti-semitismo, revelando-o através de frases de um autor que possui legitimidade suficiente para dar veracidade à causa; e des-

10 RACISMO: O marxismo anti-judaico. Páginas de Combate. n. 3, jun. 1999. Disponível em: $<$ http://members.Xoom.com/ XOOM/integralismo $>$. 
merecer o marxismo aos olhos do público, acusando-o de racista, por meio da desfiguração do caráter da obra citada.

Nos discursos neo-integralistas, configuram-se duas imagens opostas dos judeus: capitalista e comunista. A presença simultânea dessas duas imagens contraditórias revela um paradoxo: se as chamadas "práticas judaicas" de cunho capitalista são resultado de tendências étnico-raciais, como o judeu pode ser ao mesmo tempo capitalista e comunista, visto que são doutrinas e práticas completamente excludentes? Somente uma interpretação das ideologias e práticas sociais com base nos interesses e na consciência de classe poderia explicar esse paradoxo. Mas, tal interpretação está ausente do discurso neo-integralista, pois derrubaria o suporte de sua argumentação anti-semita: a explicação do comportamento social e político do judeu a partir do determinismo racial.

A partir do momento que o movimento neo-integralista desconsidera totalmente a análise classista e baseia-se no preconceito racial ao falar do judaísmo e dos judeus em geral, passa a defender um discurso contraditório. Para driblar esse problema, o movimento constrói uma imagem falsa do comunismo, reduzindo-o ao chamado materialismo. Assim, os judeus são classificados como materialistas, o que seria a ponte que une judeus capitalistas e comunistas. Todo o discurso contra o capitalismo e o comunismo é permeado pela crítica ao materialismo, subestimando-se as diferenças substanciais entre as duas ideologias. Vejamos:

Acreditamos que tanto o liberalismo capitalista e o socialismo marxista não são doutrinas coerentes com a nossa realidade, pois se baseiam no materialismo, afastando o cidadão do espiritualismo e, sendo assim, não o valorizando pelo que é, mas pelo que possui. ${ }^{11}$

$\mathrm{Ou}:$

Tanto o liberalismo quanto o socialismo são apenas uma maquiagem dos dois sistemas que oprimem o ser humano em

11 CONTRA o marxismo, o capitalismo e a degeneração do ser humano. Disponível em: $<$ http://www.integralista.cjb.net/>. 
função da falta de espiritualidade de ambos. O capitalismo é maquinado pelo banqueirismo internacional, que manipula as finanças mundiais, criando dívidas, que tornam países devedores de uma cúpula de "agiotas". O comunismo é maquinado por agitadores políticos, que usam como tática revolucionária o ateísmo, o aborto, a legalização das drogas e outras "bandeiras" na função de criar um caos social para desmoralizar o capitalismo e promover a troca de poder. ${ }^{12}$

$\mathrm{O}$ anti-semitismo neo-integralista também pode ser percebido no discurso do movimento sobre o sionismo. Nesse sentido, cabem os seguintes questionamentos: qual a natureza da análise neo-integralista acerca do sionismo? Qual o seu papel no conjunto da doutrina do movimento? Para responder a essas questões, é preciso ressaltar que a análise neo-integralista sobre o sionismo está eivada de ideologia, pois a introdução da questão sionista no discurso do movimento tem o objetivo primordial de difamar os seus "eternos" adversários: os judeus, e não realizar uma verdadeira compreensão da natureza do sionismo. Porém, como algumas verdades são utilizadas para reforçar o anti-semitismo, a definição de Zizek ${ }^{13}$ (s. d., p. 12) para o termo "ideologia" é bastante apropriada para a desconstrução do discurso neo-integralista. Ele estabelece que a questão do enunciado ser verdadeiro ou falso não é o mais importante, visto que a ideologia também está presente em discursos cujo conteúdo é verdadeiro. Nesse caso, é preciso atentar, não para o enunciado em si, mas para os processos ideológicos que estão por trás do discurso. A ênfase é dada na intencionalidade do discurso e nos interesses que ele encobre, a despeito da veracidade ou não de seu conteúdo.

Por trás de algumas verdades ditas pelos neo-integralistas, é preciso buscar as suas intenções, que podem ser visualizadas por meio das omissões e contradições presentes no desenvolvimento dos argumentos antisionistas. Omissão acerca da história do movimento sionista e do seu caráter cultural; o desprezo pelo real significado do movimento, reduzindo-o a simples reflexo de um comportamento determinado pela raça; crítica ao

12. INTEGRALISMO 1999. Páginas de Combate, n. 1, abr. 1999. Disponível em: <http:// members.xoom.com/_XOOM/integraliismo>.

13. ZIZEK, S. Um mapa da ideologia. Rio de Janeiro: Contraponto, [19-?]. 
sionismo simultaneamente à defesa de outros movimentos com características parecidas ou iguais às atribuídas aos sionistas. Eis alguns exemplos de como o sionismo é tratado no discurso neo-integralista e que demonstram o caráter ideológico da análise feita pelos adeptos do movimento.

A crítica neo-integralista ao sionismo é feita relacionando-se o caráter sionista ao "povo judeu" como um todo, resultando na intolerância e no preconceito e na fomentação do ódio e do anti-semitismo. A complexidade da questão sionista é reduzida em prol de uma interpretação niveladora e preconceituosa em relação a todo um povo, com o objetivo de legitimar as ações anti-semitas perpetradas pelo regime nazista.

Um exemplo é a análise de um material muito interessante apresentado pelos próprios neo-integralistas. Trata-se da plataforma da entidade "Chazit HaNoar Hadrom Amerikait", pertencente ao movimento sionista, que possui organizações nas cidades brasileiras de Porto Alegre, São Paulo e Rio de Janeiro, e em Montevidéu, no Uruguai. ${ }^{14}$ Esta entidade define o sionismo como um movimento de liberação nacional por meio da concentração territorial e cultural do povo judeu no Estado de Israel. O caráter ideológico no trato da questão sionista pelo neo-integralistas transparece logo no título com que eles apresentam a plataforma da referida entidade. $\mathrm{O}$ título é "Ideologias Políticas no Brasil: Sionismo no Brasil - O Que Querem? O Que é o Movimento de Extrema-Direita ‘Sionismo' por Sionistas?"15

O principal a ser destacado no título acima é o uso do conceito "extrema-direita" para designar o sionismo. Ocorre uma operacionalização ideológica do conceito. Por que ele é utilizado? Ele é esclarecedor da natureza do movimento em questão? Como o conceito é usado? O seu uso tem o propósito de difamar o movimento sionista, e não de compreendê-lo. $\mathrm{O}$ conceito não esclarece em nada a natureza do sionismo, visto que sequer é acompanhado de uma definição das características ideológicas dos movimentos abarcados sob tal conceito. Além disso, o conceito é utilizado de forma descolada da fonte citada, pois a plataforma sionista apresentada pelos neo-integralistas não apresenta relação alguma com um movimento

14. Trata-se de um movimento juvenil, com pretensões educativas por meio da transmissão da educação não formal do jovem pelo jovem. A estrutura do movimento é organizada em grupos etários, a fim de evitar que a liderança se concentre em uma só pessoa.

15. PÁGINAS de Combate. n. 3, jun. 1999. Disponível em: <http://members.xoom.com/ _XOOM/integralismo>. 
de extrema-direita, se considerarmos a discussão feita pela literatura especializada no tema. Segundo esta literatura, a ideologia de um movimento de extrema-direita apresenta pelo menos cinco aspectos: o nacionalismo, a xenofobia, o racismo, a antidemocracia e a defesa de um Estado forte. ${ }^{16}$ Tais fatores devem aparecer de forma combinada, o que não acontece no trecho seguinte da plataforma do movimento sionista citado pelos neointegralistas:

\begin{abstract}
Vemos no judaísmo a resultante da elaboração cultural do Povo Judeu ao longo de sua história; e reconhecemos nele uma gama de valores e tradições que devemos conhecer e vivenciar, bem como transmitir. Consideramos que os valores nacionais judaicos, valores éticos e religiosos, tradições e costumes, constituem um todo coerente e como tal o encaramos. É nosso ideal garantir e contribuir para a continuidade do Povo Judeu [...]. Vemos no sionismo o movimento de liberação nacional, pelo qual, o Povo Judeu está processando sua concentração territorial e cultural no Estado de Israel, processo este para cuja aceleração devemos e desejamos contribuir. ${ }^{17}$
\end{abstract}

Se formos analisar o trecho acima, a única conclusão que podemos tirar é que o movimento sionista defende a autonomia cultural do povo judeu, por meio da defesa dos valores judaicos e da nação judaica. O Estado de Israel é visto como o defensor do povo judeu e como garantia de sua sobrevivência enquanto nação autônoma. Dessa forma, a questão a ser colocada é a seguinte: qual a relação entre tal concepção do sionismo e o conceito de extrema-direita? Como podemos ver, nenhuma. $\mathrm{O}$ nacionalismo aparece na plataforma, mas não de forma associada à intolerância ou ao racismo em relação a outros povos, e sim associado ao desejo de preservar a cultura e os valores judaicos.

Apesar dos neo-integralistas ressaltarem que esta entidade sionista é um movimento de extrema-direita, existem trechos da sua plataforma que

16 MUDDE, Cas. Right-Wing Extremism Analyzed: a comparative analysis of the ideologies of three alleged right-wing extremism parties (NPD, NDP, CP' 86). European Journal of Political Research, v. 27, n. 2, 1995.

17 PÁGINAS de Combate. n. 3, jun. 1999. Disponível em: <http://members.xoom.com/ _XOOM/integralismo>. 
afirmam claramente o caráter não intolerante do movimento. O mais significativo é o seguinte:

A posição nacional do jovem não implica o isolamento da realidade e problemática mundial. Devemos considerar que a educação nacional não leva a uma exaltação nacionalista e fundamentalista. $^{18}$

Este é um exemplo de como os neo-integralistas desconsideram o conteúdo do discurso do movimento sionista citado em prol do uso de um conceito que não possui relação alguma com o objeto em questão.

A partir do momento que os neo-integralistas não discutem a definição do conceito utilizado e, ainda por cima, apresentam como fonte uma plataforma sionista que não se relaciona com os aspectos da ideologia de extrema-direita discutida pela literatura especializada, a única conclusão que se pode tirar é que o conceito é usado fora de lugar, com o propósito de difamar os judeus como um todo. Assim, a operacionalização do conceito é ideológica, não visando à compreensão da natureza do movimento sionista, e sim à sua deslegitimação política.

A plataforma sionista citada possui trechos que revela qual é, de fato, o real motivo das críticas neo-integralistas ao movimento. Eles aparecem quando o movimento fala da questão da educação nacional. São eles:

A conscientização do jovem de que pertence ao Povo Judeu, através da identificação e do compromisso com os valores e realizações de seu povo [...]. Seguindo o método de questionamento, mostrar que a assimilação significa a negação da condição de pertinência ao Povo Judeu, bem como de sua nacionalidade, e a Galut (diáspora) como modo de vida não integral do seu ser judeu, o que não assegura a continuidade do nosso povo [...]. O jovem judeu deve chegar a sua consciência de identificação nacional por uma própria valorização de seu ser nacional judeu, como resultado de seu processo educacional. ${ }^{19}$

18 Id

19 Id. 
Percebe-se, no trecho acima, que o referido movimento sionista defende a preservação da cultura judaica e baseia a nacionalidade do povo judeu nessa cultura. Aqui está o ponto nevrálgico para os neo-integralistas: a recusa da assimilação à cultura dos países em que os judeus residem e a defesa da identificação dos judeus com a nação judaica.

Assim, quando os neo-integralistas procuram difamar o sionismo sob a pecha do conceito de "extrema-direita", estão, na verdade, demonstrando a sua intolerância em relação à preservação de identidades culturais não assimiladas ao ideal e ao projeto de nação defendidos pelo movimento. Não se preocupam com o sionismo porque ele é um movimento de extrema-direita, e sim porque o sionismo é um movimento de judeus que querem manter a cultura e a nacionalidade judaica. É importante enfatizar que a preocupação dos neo-integralistas é muito mais pelo sionismo ser um movimento de judeus do que pelo fato de ser um movimento que defende a identidade e a cultura de um povo. Não se trata de um povo qualquer, mas de judeus. Daí o anti-sionismo neo-integralista ser essencialmente antisemita.

O caráter anti-semita do anti-sionismo neo-integralista aparece na associação que o movimento faz entre sionismo e teoria da conspiração judaica. As referências às imagens dos judeus como "opressores" e ligados ao capitalismo internacional e à globalização são muitas vezes acompanhadas do termo "sionismo". Em alguns trechos de seus discursos aparecem expressões como "establishment Sionista-Plutocrático", por exemplo. A teoria da conspiração, tese já defendida pelos velhos integralistas e reeditada pelo atuais seguidores do sigma, baseia-se numa explicação racial para o comportamento político e social de grupos judaicos e, dentro dessa lógica discursiva, a origem do sionismo é totalmente descontextualizada. Os neointegralistas desconsideram uma série de questões ligadas à história do sionismo, na tentativa de apresentá-lo como parte integrante da natureza do povo judeu enquanto opressor e explorador de outros povos.

O sionismo, enquanto movimento político nacionalista, é relativamente recente e sua natureza sofreu mudanças profundas no decorrer de sua história, vinculadas às circunstâncias específicas relacionadas à colonização sionista da Palestina e ao surgimento do Estado de Israel. Se o sionismo adquiriu um caráter racista e intolerante, é preciso atentar para o fato de que, em sua origem, o movimento não tinha esse caráter, e não estava sequer associado à questão da identidade nacional judaica, tendo se origina- 
do num contexto em que as diferenças sociais entre o povo judeu contavam muito mais do que a unidade cultural que, devido às diferentes situações sociais que dividiam judeus ocidentais de judeus orientais, não existia.

A consideração da história das origens do sionismo nos revela aspectos negligenciados pelos neo-integralistas, em sua tentativa de simplificar a questão do sionismo, associando-o a um determinismo racial e utilizando-o como justificativa do anti-semitismo. Tais aspectos são os seguintes: a) a ligação inicial do sionismo com as diferenças sociais e de classe no seio do povo judeu, e não com a questão nacional; b) as divergências entre os pensadores judeus a respeito da questão nacional e do sionismo, trazendo à tona o fato de que nem todos concordavam com o estabelecimento de um Estado judeu, priorizando mais a questão espiritual e cultural do povo judeu do que a questão política; c) o predomínio, nos grupos judaicos socialistas, da questão social sobre a nacional, sob a forma de conflito entre identidade de classe $\mathrm{x}$ identidade nacional-burguesa.

Esses aspectos revelam que o comportamento político dos judeus deve ser explicado pela situação social e cultural em que se encontram, e não por uma essência judaica, ou pela "raça". Quando os neo-integralistas desconsideram as divergências internas no judaísmo a respeito da questão sionista, estão procurando explicações simplistas para o sionismo, a saber, a idéia de que todos os judeus são naturalmente opressores de outros povos e tendem, por isso, à defesa do sionismo enquanto representante máximo de tal "natureza" judaica.

O movimento neo-integralista, portador de uma ideologia baseada na exclusão e na intolerância, tem um discurso específico no que toca às relações entre o projeto de nação e a questão das diferenças culturais e raciais. O racismo neo-integralista é herdeiro da ideologia racista do integralismo dos anos 30, cujos princípios o atual movimento procura resgatar em seus discursos. O conceito de nação, nos discursos do movimento, exprime, entre outras coisas, a idéia de uma sociedade homogênea, do ponto de vista cultural e racial.

Este último ponto, a homogeneidade cultural e racial, revela-se nos discursos contrários à manutenção das identidades culturais de comunidades de imigrantes, no Brasil, dentre elas, os judeus; na defesa da nacionalização desses grupos; no ideal do amálgama racial, ou seja, da miscigenação com conotações racistas, já que tem o firme propósito de branquear a população brasileira e formar uma raça única: a raça branca. O princípio 
nacionalista está presente nos discursos neo-integralistas e engloba as críticas que são feitas aos elementos não-assimilados à cultura nacional e a defesa da homogeneidade étnica e cultural do povo brasileiro, por meio do amálgama racial. É dentro desse contexto que se deve analisar as críticas dos neo-integralistas ao sionismo.

Os velhos e novos integralistas compartilham de algumas idéias que circulavam do final do século XIX até meados do século XX no Brasil, notadamente a idéia de que o problema racial é um problema nacional, resultando disso que o discurso racista do movimento está profundamente ligado a uma determinada concepção de nação.

O neo-integralismo herda a concepção racista dos velhos integralistas, que, longe de defender abertamente o racismo de tipo nazista, construíram um discurso específico em relação à questão racial, condicionado pela cultura de miscigenação da sociedade brasileira. A defesa da miscigenação era usada, inclusive, como estratégia de luta contra as diferenças culturais e étnicas, em prol de um projeto homogeneizante. ${ }^{20}$

A idéia da miscigenação, enquanto manifestação da intolerância étnica e cultural e como instrumento de um projeto homogeneizante do povo brasileiro, presente nos discursos dos velhos integralistas, sobrevive na fala dos neo-integralistas. Eles argumentam que o racismo é um sentimento contrário à realidade de um país mestiço, permeado pelo cruzamento entre as raças, desde suas origens.

Um exemplo é o discurso de Gumercindo Rocha Dorea, que nega qualquer ligação entre ele e os grupos racistas na América Latina, afirmando:

Minhas informações sobre a existência desses grupos no Brasil são as publicadas pela nossa imprensa. Tenho sido procurado por jovens e lhes tenho dado uma só orientação: o nosso momento histórico é totalmente diferente de 30, 40 ou 60 anos atrás; que eles, na sua ansiedade e ousadia naturais, busquem novos instrumentos de luta, e que encontrem em seus estudos e ambição político-cultural outros meios de renovação, jamais,

20 CRUZ, N. O Integralismo e a questão racial: a intolerância como princípio. 302f. Tese (Doutorado em História Política) - Universidade Federal Fluminense, Niterói, 2004. 
porém, fundamentando-se em ódio a outros povos ou raças. $^{21}$

Outras duas questões foram feitas a Dorea: qual tipo de idéia os grupos racistas defendem e se há espaço no Brasil para grupos racistas, levando-se em conta a cultura brasileira. À primeira pergunta ele responde da seguinte forma:

\begin{abstract}
Não sei se o que a imprensa brasileira publica corresponde à verdadeira pregação desses grupos racistas. Independente disto, porém, o racismo e a xenofobia são bandeira indefensáveis no mundo em que vivemos, no Brasil, sobretudo. Nossa formação étnica é o maior desmentido aos fundamentos racistas de qualquer ideologia. ${ }^{22}$
\end{abstract}

Quanto à segunda questão, a resposta contradiz a citada acima. $\mathrm{O}$ racismo é considerado indefensável, mas os grupos que o defendem são, ao contrário, defendidos. Vejamos:

Têm esses grupos racistas, entretanto, o mesmo direito de proclamar suas idéias, por mais erradas que sejam, como tem os que defendem idéias comunistas. Os exemplos da História na fazem parte de seu patrimônio cultural. ${ }^{23}$

A conclusão que se pode tirar desses depoimentos é a de que os neo-integralistas negam o racismo mas defendem os grupos neonazistas; conseqüentemente, defendem também o racismo. As informações que a imprensa divulga a respeito dos grupos racistas são colocadas sob suspeita e tais grupos são apresentados como portadores do direito de expressarem seu ideário. Dessa forma, os neo-integralistas, assim como os neonazistas, consideram o racismo a simples expressão de uma idéia, e não um crime, como prevê a Constituição Brasileira de 1988. Além disso, o direito dos

21 PÁGINAS de Combate. n. 3, jun. 1999. Disponível em: <http://members.xoom.com/ _XOOM/integralismo>.

22 Id.

23 Id. 
racistas de exprimir suas idéias é justificado pelo direito que os comunistas possuem de expressar sua doutrina, conforme a fala anterior de Dorea. No entanto, trata-se de doutrinas e idéias incomparáveis, pois, enquanto o racismo é crime, o comunismo é apenas uma ideologia que prega a transformação econômica e social da sociedade, não se constituindo em crime algum.

O racismo, porém, é uma das formas em que a intolerância se manifesta no discurso neo-integralista. A outra forma é a xenofobia, que pode se entendida como um conflito intergrupos, por diferenças culturais e/ou raciais, vistas como uma ameaça às identidades nacionais. Cabe ressaltar que a xenofobia pode vir acompanhada do racismo, embora nem sempre isso ocorra. O conceito de racismo tem sido empregado para designar qualquer tipo de intolerância ou reação às diferenças, fazendo com que o conceito torne-se banalizado e superexplorado nas análises que versam sobre a questão da intolerância.

Um dos exemplos é a criação do conceito de "novo racismo"24, que é usado para explicar a aversão e culturas e costumes diferentes e pela defesa da separação entre as diferentes culturas, mantendo-se a integridade de cada uma. O novo racismo seria a manifestação de movimentos e configurações da sociedade global em formação, pautada pelas migrações transnacionais - deslocamentos de indivíduos, famílias e coletividades para sociedades semelhantes ou radicalmente distintas em termos culturais. ${ }^{25}$

O conceito de "novo racismo" é usado para demarcar a diferença entre o racismo clássico e os novos tipos de conflito, que não se baseiam na dicotomia superioridade-inferioridade, e sim na defesa das identidades culturais de grupos e nações. No entanto, embora no bojo do racismo clássico também esteja a defesa de identidades nacionais, não se pode desprezar que a especificidade do discurso racista está na afirmação de que determinadas culturas são superiores a outras, tendo como suporte a idéia de superioridade racial.

Assim sendo, o que o chamado "novo racismo" tem de novo é exatamente aquilo que o diferencia do racismo propriamente dito, sendo

BARKER, M. The new racism: conservatives and the ideology of the tribe. London: Junction Books, 1981.

25 IANNI, O. A racialização do mundo. Tempo Social, São Paulo, v. 8 n. 1, p. 1-23, maio 1996. 
este definido como o preconceito pelos diferentes com base no ideal de superioridade racial. A partir do momento que as diferentes culturas entram em conflito por causa da necessidade de manutenção de suas próprias identidades, mas constroem seu discurso somente na defesa da separação das culturas diversas, não fazendo referências a supostas inferioridades ou superioridades de umas em relação a outras, não se pode falar em racismo. Se o discurso se pauta pela idéia de que todas as culturas têm direito ao livre desenvolvimento, porém, separadas, pode-se falar em intolerância e exclusão, na incapacidade das culturas conviverem pacificamente e aproveitarem a convivência para a troca e o crescimento mútuo. Mas isso não pode ser considerado sinônimo de racismo. Considero mais apropriado, neste caso, o conceito de "heterofobia", utilizado por Bauman (1998, p. 84) que também critica o uso desmesurado do conceito de racismo.

Os neo-integralistas apresentam em seu discurso tanto o antigo ideal racista como atitudes xenófobas e heterofóbicas, em virtude de sua inserção em um mundo cada vez mais globalizado, no qual o contato com culturas diversas ocorre com mais intensidade. A xenofobia, porém, também é negada pelos neo-integralistas, embora apareça claramente nos documentos produzidos pelo movimento, associada à luta contra a globalização:

\begin{abstract}
A moda do momento esta em torno da "globalização", tão decantada em prosa e verso, como a panacéia que resolverá todos os problemas do mundo, pois "cairão as fronteiras dos países, todos seremos irmãos e os problemas advindos das fronteiras terminarão". Será tão simples assim? Senão vejamos: o que cada país tem de mais sagrado para si? Sua cultura, seu regionalismo, seus costumes, língua, povo, enfim, numa palavra, a sua nacionalidade! E como ficará a Nacionalidade de cada país face à globalização? ${ }^{26}$
\end{abstract}

A globalização, portanto, significaria o contato com outras culturas e outros povos, o que contribuiria para a descaracterização da nacionalidade brasileira. É uma postura claramente xenófoba e heterofóbica.

26 O INTEGRALISMO face à globalização. Páginas de Combate, n. 3, jun. 1999. Disponível em: $<$ http://members.xoom.com/XOOM/integralismo $>$. 


\section{Conclusão}

O neo-integralismo é uma tentativa de reviver os ideais integralistas dos anos 30, readaptando-os ao contexto atual, inserindo as temáticas da globalização e os problemas atuais do país dentro da doutrina nacionalista do movimento. No entanto, persistem a intolerância e a exclusão, que baseiam um nacionalismo extremamente conservador, do qual fazem parte concepções racistas - disfarçadas sob a apologia da miscigenação - e antisemitas, reeditando-se a antiga tese da conspiração judaica.

$\mathrm{Na}$ tentativa de construir uma memória do integralismo e tornar as idéias neo-integralistas aceitáveis, o movimento busca negar o anti-semitismo e qualquer aproximação do integralismo com o nazismo, considerado racista e contrário ao humanitarismo cristão do movimento. Para legitimar a memória do integralismo, membros do movimento atual apelam para o relativismo, baseando-se em discussões metodológicas e epistemológicas acerca da construção do passado histórico - discussões estas que fazem parte da consolidação da história como ciência. Um exemplo é o trecho abaixo:

[...] notamos a importância da ideologia e do relativismo cultural
que são inerentes ao processo de pesquisa, sendo possível
estabelecer que não existe, e nunca poderá existir, uma história;
ou melhor, versões históricas definitivas. Sem dúvida, ter em
mente essa visão desconstrutiva da história-devir como ciência
é útil a qualquer historiador ou escritor que deseje buscar,
através de uma versão diferenciada da conhecida história
"oficial", abalar as estruturas do chamado "establishment", que
é amplamente embasado em discursos "históricos" necessários
para criar as prerrogativas que estão embutidas, sustentam e
dão significado aos discursos dos arautos do expediente político-
ideológico vigente. ${ }^{27}$

Trata-se de uma estratégia discursiva que visa contestar as interpretações da historiografia que associam o integralismo ao nazismo e ao

27 SILVEIRA, 2004, op. cit. 
fascismo, as quais teriam o objetivo de denegrir a imagem do movimento. Nesse sentido, os neo-integralistas procuram afastar as concepções integralistas do fascismo e do nazismo:

Está aqui posto, pois, o grande problema para aceitação da sociedade com relação ao Integralismo: a pecha de fascismo; ou, no entender dos poucos mais jovens que se aproximaram superficialmente do tema, uma mera espécie de imitação de fascismo na sua versão tupiniquim. Mais ainda: o denominado "fascista" se tornou, por tabela, o mesmo que "nazista"; que é hoje, para o homem comum, uma das mais graves ofensas. Fortemente inspirado pela Doutrina Social da Igreja Católica, por Farias Brito e Jackson Figueiredo, Plínio Salgado foi um bravo combatente das teorias deletárias, e fez o Integralismo livre dos excessos do fascismo com relação à inversão dos papéis do Estado e da Nação. A qual, para ele, deveria emoldurar o primeiro, e não o contrário.

Afastando de suas concepções o finalismo imanente do culto ao Estado expresso na visão de Hegel e, portanto, repudiando a idéia do totalitarismo como forma de coerção e anulação completa do indivíduo, defendeu o Chefe Nacional que o homem não deve perder sua personalidade e o justo equilíbrio entre a Família, a Sociedade e o Estado.

Reconhecem, no entanto, que havia compartilhamento de valores e ideais, como a defesa da hierarquia, da disciplina, da supremacia do Estado, do antiliberalismo e do anticomunismo. Porém, a negação do racismo e do anti-semitismo, traz à tona um processo de construção da memória extremamente seletivo, ocultando-se os elementos que possam prejudicar a imagem que se quer passar do passado histórico integralista. Os adeptos atuais do movimento pretendem excluir da história do integralismo os membros e as suas obras anti-semitas, como se estes não fizessem parte da ideologia e da filosofia de vida integralistas. Embora seja importante reconhecer que o integralismo não era um movimento homogêneo, e que possivelmente havia adeptos que discordavam das teorias anti-semitas, é verdade também que tais teorias eram defendidas e faziam parte da fala de várias lideranças do sigma.

A questão do racismo torna-se central no processo de desmistificação do discurso neo-integralista, na medida em que o movimento utiliza-se 
da forma específica que a questão racial toma em sua ideologia nacional para apartá-lo do presente e do passado da ideologia nazista, demarcando fronteiras supostamente intransponíveis entre as duas ideologias. Tal estratégia faz parte do processo de construção de uma imagem positiva do integralismo, com vistas a legitimá-lo junto à opinião pública. Assim sendo, o centro dessa estratégia é a negação do racismo enquanto parte da ideologia nacional dos velhos e novos integralistas.

Embora a negação do racismo e seu encobrimento na teoria do amálgama racial já fizessem parte do discurso dos velhos integralistas, a presença dessa estratégia discursiva na fala dos neo-integralistas é permeada por dois fatores que marcam as diferenças entre o integralismo dos anos 30 e o atual: 1) A necessidade de construir uma falsa memória sobre a AIB, visando dar credibilidade ao neo-integralismo junto à opinião pública; 2) A presença de um contexto histórico no qual os valores democráticos ganham força no imaginário político e social.

Os dois fatores estão interligados. Nos anos 30 e 40, a conjuntura política era diferente, marcada principalmente pela ascensão dos ideais autoritários e excludentes, o que tornava o racismo apenas mais um dos elementos que compunham o quadro de uma sociedade que se imaginava desigual e aceitava essa desigualdade como natural. Atualmente, porém, a preocupação em construir uma "história" mais aceitável da AIB, em que os seus aspectos negativos sejam ocultados ou disfarçados, coaduna-se com a tentativa de conciliar um movimento que possui um discurso racista ultrapassado com os valores da sociedade atual, na qual o ideário racista e excludente é intolerável. 